\title{
Electrocardiogram assessment in non-anaesthetized clinically healthy agouti (Dasyprocta primnolopha, Wagler 1831) ${ }^{1}$
}

\author{
Anaemilia das N. Diniz ${ }^{2}$, José R. da Silva Júnior ${ }^{3}$ Porfírio Candanedo Guerra ${ }^{3}$, Raimundo A. \\ Barreto-Júnior ${ }^{4}$, Hatawa M. Almeida ${ }^{2}$, Larisse D. Freire ${ }^{5}$, Carlos E. Ambrósio $^{6}$ \\ and Flávio R. Alves ${ }^{7 *}$
}

\begin{abstract}
Diniz A.N., Silva Júnior J.R., Guerra P.C., Barreto-Junior R.A., Almeida H.M., Freire L.D., Ambrósio C.E. \& Alves F.R. 2013. Electrocardiogram assessment in nonanaesthetized clinically healthy agouti (Dasyprocta primnolopha, Wagler 1831). Pesquisa Veterinária Brasileira 33(Supl.1):8-14. Departamento de Morfisiologia Veterinária, Curso de Medicina Veterinária, Universidade Federal do Piauí, Campus Universitário Ministro Petrônio Portella, Bairro Ininga, Teresina, PI 64049-550, Brazil. E-mail: flavioribeiro@ufpi.edu.br

The agouti is one of the most intensely hunted species throughout the Amazon and the semiarid regions of north-eastern Brazil. Considering the current tendency of wild animal management in captivity, the objective of this study was to determine heart reference values for agouti raised in captivity, based on electrocardiographic assessments (ECG). Adult agouti were selected without clinical signs of heart disease $(n=30)$. The animals were restrained physically and then the ECG was performed. Standardized measurements were taken to establish the statistical analysis of the data. Analysis of the QRS complex showed values compatible with previous reports in peer animals and the limited data available for other wild and exotic species, except for the $\mathrm{T}$ wave that showed similar amplitude to the $\mathrm{R}$ wave in all the animals studied. The data obtained provided the first reference values for ECG tracings in agouti, contributing to a better understanding of heart electrophysiology in identifying myocardial pathology in these animals.
\end{abstract}

INDEX TERMS: Agouti, Dasyprocta primnolopha, wild mammals, electrocardiography, cardiology.

\footnotetext{
${ }^{1}$ Received on June 21, 2013.

Accepted for publication on November 11, 2013.

${ }^{2}$ Programa de Pós-Graduação em Ciência Animal, Universidade Federal do Piauí (UFPI), Campus Universitário Ministro Petrônio Portella, Bairro Ininga, Teresina, PI 64049-550, Brazil.

${ }^{3}$ Departamento das Clínicas, Curso de Medicina Veterinária, Universidade Estadual do Maranhão (UEMA), Campus Paulo VI s/n, São Luís, MA 65055-310, Brazil.

${ }^{4}$ Departamento de Clínicas, Curso de Medicina Veterinária, Universidade Federal do Semi-Árido (UFERSA), Av. Francisco Mota, Bairro Costa e Silva, Mossoró, RN 59625-900, Brazil

${ }^{5}$ Serviço de Diagnóstico por Imagem, Hospital Universitário Veterinário, Universidade Federal do Piauí (UFPI), Campus Universitário Ministro Petrônio Portella, Bairro Ininga, Teresina, PI.

${ }^{6}$ Departamento de Ciências Básicas, Faculdade de Zootecnia e Engenharia de Alimentos, USP, Av. Duque de Caxias Norte 225, ZAB, Pirassununga, SP 13635-900, Brazil.

${ }^{7}$ Departamento de Morfisiologia Veterinária, Curso de Medicina Veterinária, Universidade Federal do Piauí (UFPI), Campus Universitário Ministro Petrônio Portella, Bairro Ininga, Teresina, PI. *Corresponding author: flavioribeiro@ufpi.edu.br
}

RESUMO.- [Avaliação do eletrocardiograma em cutias (Dasyprocta primnolopha, Wagler 1831) não-anestesiadas clinicamente saudáveis.] A cutia é uma das espécies mais intensamente caçados em toda a Amazônia e as regiões semi-áridas do nordeste do Brasil. Considerando-se a tendência atual no manejo de animais silvestres em cativeiro, o objetivo deste estudo foi determinar os valores de referência para o coração cutia criadas em cativeiro, com base em avaliações do eletrocardiograma (ECG). Foram selecionadas cutias adultas e sem sinais clínicos de doença cardíaca $(\mathrm{n}=30)$. Os animais foram contidos fisicamente e, em seguida, o ECG foi realizado. Medições padronizadas foram tomadas para estabelecer a análise estatística dos dados. Análise do complexo QRS apresentou valores compatíveis com os relatórios pregressos em animais animais de companhia, assim como para os poucos dados disponíveis para outras espécies selvagens e exóticas, com exceção da onda $\mathrm{T}$, que mostrou amplitude semelhante à onda $\mathrm{R}$ em 
todos os animais estudados. Os dados obtidos permitiram a aquisição dos primeiros valores de referência para os traçados de ECG em cutias, contribuindo para uma melhor compreensão eletrofisiologia cardíaca, na identificação de miocardiopatia nesses animais.

TERMOS DE INDEXAÇÃO: Agouti, Dasyprocta primnolopha, mamíferos selvagens, eletrocardiografia, cardiologia, cutia.

\section{INTRODUCTION}

The agouti (Dasyprocta sp.) is a rodent mammal that occurs throughout Brazil and currently is an important species reared in captivity (Hosken 2001). Together with other wild rodents it has suffered from destruction of its habitat and predatory hunting and consequent decrease in its population (Bodmer, Eisenberg \& Redford 1997, Nogueira-Filho \& Nogueira 2000, Ribeiro et al. 2007). These are the reasons for the ever greater study of the species in an attempt to obtain greater knowledge on their physiology (Alimurung et al. 1980, Sampaio \& Batista 2004, Leal et al. 2005).

Among these animals the agouti presents both zootechnical and conservationist interest (Pinheiro et al. 1989, Lopes 2004). The establishment of conservation units and commercial rearing farms has stimulated studies regarding the acquisition of biological data of the species, especially the reproductive, health and food management characteristics, to ensure their survival in captivity (Berllago \& Cerqueira 1994, Redford 1997, Ferraz et al. 2010).

Although already discussed, establishing clinical normality criteria for wild rodents still requires further studies on their physiology and organic responses (Osofsky et al. 2001, Crissey 2004, Fox et al. 2008).

Among the parameters to be assessed, access to the heart function is important data to define the homeostatic balance in wild species (Bodmer et al. 1997, Leal et al. 2005). Most of the information on the wild animal cardiovascular system is limited to the heart and some large vessels, available mostly for laboratory rodents, and there are few reports of this information for wild species (Heatley 2009, Diniz et al. 2013).

Investigations by complimentary examinations such as the ECG are widely used in cardiologic assessments in veterinary medicine (Ware 2007). However, reference values have not yet been fully established for most wild species, and there is little information in the literature that would sustain the standardization of access techniques to the heart function and suggest alterations in this organ for these animals (Stepien 1999, Gardner et al. 2007, Estrada et al. 2009, Onuma et al. 2009, Black et al. 2011).

The electrocardiogram is a cheap diagnostic test, non-invasive and capable of registering the electric activity of the myocardium, determining the heart rhythm and frequency supplied by the P-QRS-T deflections of the electrocardiogram tracing (Hanton \& Rabemampianina 2006, Scheer et al. 2010).

With advances in information technology, the computerized electrocardiogram has been used in human medicine as an auxiliary diagnostic method and is currently used increasingly in veterinary medicine (Tilley 1981, Andrade et al. 2004, Aptekmann et al. 2010, Neto et al. 2010, Gava et al. 2011). According to Tilley (1992), in veterinary medicine, the computerized ECG improved the quality of emergency electrocardiogram services and other advantages including a decrease in the time needed to carry out the exam.

Reducing this time was fundamental when dealing with wild animals that require apparatus that presents an "elasticity" of use, due to the great variety of species that potentially can be assessed, and should have at least six basic derivations. Several wild and exotic species have already been studied by assessing their ECG tracing but these values are still little dimensioned and the variations, normality standards and electric tracings associated to disease for most of these known species are not completely defined (Blacket al. 2001, Bartlett et al. 2004, Dudás-Györki et al. 2011).

Considering that information on wild animal physiology and cardiovascular anatomy is very important and scarce, the objective of the present study was to define cardiac radiographic and electrocardiogram (ECG) normality parameters for healthy agouti without chemical restraint, kept in captivity, to contribute to the acquisition of data that can be used as normal parameters for the species and help in identifying possible alterations.

\section{MATERIALS AND METHODS}

\section{Animals}

Thirty agouti (Dasyprocta primnolopha) were used, 1-3 years of age, weighing from $1.670 \mathrm{~kg}$ to $2.950 \mathrm{~kg}$ divided into two groups of 15 males and 15 females separated in collective stalls. The animals came from the Wild Animal Study and Preservation Nucleus - NEPAS (Registration Certificate IBAMA/PI № 02/08618 ) at the Agrarian Science Centre (CCA) of the Federal University of Piauí (UFPI). They were healthy at clinical examination and the hematological profile was normal (Ribeiro et al. 2008). The food management consisted of commercial feed (minimum crude protein $12 \%$, ether extract $1.5 \%$, fibrous material $12 \%$, calcium $1.3 \%$ and phosphorus $0.4 \%$ ) in addition to corn, regional fruit and vegetables and water ad libitum. The experimental protocol was approved by the Committee of Ethics in Animal Experimentation (CEEA) of the Federal University of Piauí-UFPI (Protocol no. $0117 / 2010$ ) and authorized by the Authorization and Information in Biodiversity System - SISBIO - ICMBio/IBAMA (Protocol 26101-1).

The animals were restrained physically and kept in right lateral decubitus on a semiological examination table (M-351) with the thoracic limbs raised cranially, pelvic limbs lowered caudally. The heart and respiratory function was assessed using a stethoscope (Littmann Cardiology III ${ }^{\circledR}$, São Paulo, Brazil) to observe the normal hyphonesis of the heart noises, respiratory frequency and sonority of the lung fields (current volume normality).

The electrocardiograms were performed by the computerized method, using the computerized electrocardiogram TEB ${ }^{\circledR}$ (TEB, São Paulo, Brazil), consisting of an electronic circuit coupled to a notebook, and software installed on the computer hard disk.

The animals were restrained physically on the insulated surface in lateral decubitus and placed as previously described to acquire electrocardiogram tracing in mammals (Fig.1) (Tilley 1992). The electrodes were distributed over the animal's body in standardized combinations following methodology described by Gava et al. (2011). The electrodes on the right and left thoracic limbs were placed above the olecranum, in its caudal aspect and the electrodes on the right and left pelvic limbs above the patella 


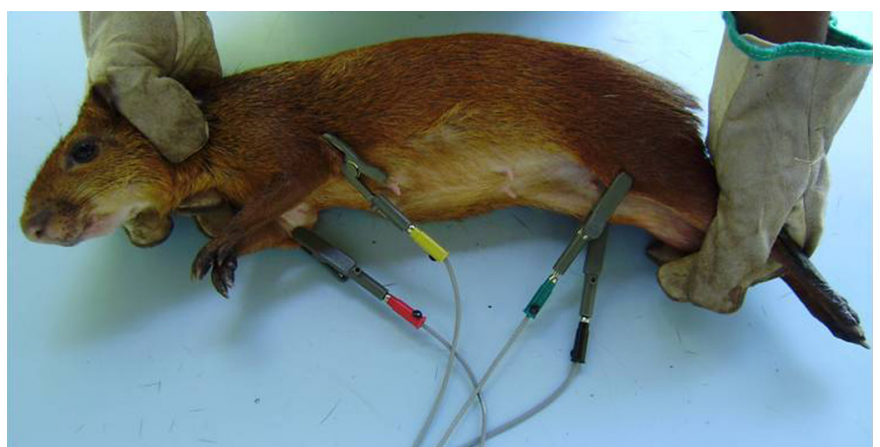

Fig.1. Agouti (Dasyprocta primnolopha) positioned to acquire the electrocardiogram tracing.

ligaments of each limb. The speed used was $25 \mathrm{~mm}$ per second, with voltage calibration of $1 \mathrm{~cm}$ for each millivolt $(1 \mathrm{mV}=10 \mathrm{~mm})$.

The heart rhythm and frequency were assessed, durations (seconds - s) and amplitude (millivolts - mv) of the P wave, PR interval and QRS complex, R wave amplitude, leveling of the ST segment, QT interval and T wave polarity, all analyzed in the bipolar II derivation (DII). The electrocardiogram measurements were analyzed following description by Tilley (1992). The tracings were analyzed in the electronic program of the electrocardiogram. The heart electric axle was determined by observing the derivations in the front plane by the sum of the positive and negative deviations in derivations I and III proposed by Tilley (1992).

\section{Statistical analysis}

The data were submitted to the normal error distribution test (Shapiro-Wilk and Kolmogorov-Smirnov test) and later in the means of the male and female groups were analyzed by the student t-test prepared for parameter interpretation, considering a confidence interval of $5 \%(p<0.05)$.

\section{RESULTS}

The animals used in the experiment presented mean weight values of $2.32 \pm 0.30 \mathrm{~kg}$ and maximum and minimum limits from 1.67 to $2.95 \mathrm{~kg}$. The electrocardiogram tracings were obtained without artifacts for muscular tremors and the parameters assessed are shown in Table 1 (Heart frequency, $\mathrm{P}$ wave duration and amplitude, QRS complex duration, the QT interval duration and $\mathrm{R}$ wave amplitude), comparatively to adult wild and exotic species. The characteristic ECG tracings for agouti males and females are shown in Figure 2b,c.

The heart frequency (HF) observed for the male presented mean values of $193.42 \pm 25.39 \mathrm{bpm}$. Although the females demonstrated lower mean HF values $(181.56 \pm 30.70$ bpm), statistical differences were not observed among the means when the males and females were compared $(p=0.18, p>0.05)$. The values measured for $\mathrm{P}$ wave duration and amplitude were, respectively, $0.036 \pm 0.0083(\mathrm{~s})$ and $0.115 \pm 0.04(\mathrm{mV})$ for the males and $0.038 \pm 0.0099(\mathrm{~s})$ and $0.104 \pm 0.04(\mathrm{mV})$ for the females. The paired study of these data did not show statistical differences for these values (duration: $p=0.51$; amplitude: $p=0.065, p>0.05$ ). The mean values for the PR interval duration, QRS complex duration, QT interval duration and $\mathrm{R}$ wave amplitude were, respectively, $0.065 \pm 0.0087(\mathrm{~s}), 0.050 \pm 0.0071$ (s), $0.167 \pm 0.0193$ $(\mathrm{s}), 0.36 \pm 0.20(\mathrm{mV})$ for the males and $0.075 \pm 0.0162(\mathrm{~s})$, $0.056 \pm 0.0089(\mathrm{~s}), 0.183 \pm 0.0229(\mathrm{~s}), 0.34 \pm 0.20(\mathrm{mV})$ for
Tabela 1. Valores normais das mensurações cardíacas de cutias (Dasyprocta prymnolopha, Wagler 1831) em projeções radiográficas laterais e ventrodorsais

\begin{tabular}{|c|c|c|c|c|}
\hline Variável & Unidade & Macho & \multicolumn{2}{|l|}{ Fêmea } \\
\hline $\mathrm{AB}$ & \multirow[t]{2}{*}{$\mathrm{cm}(\mathrm{cv})$} & $3,70 \pm 0,25(4,41 \pm 0,30) A$ & \multicolumn{2}{|c|}{$3,57 \pm 0,16(4,25 \pm 0,19) \mathrm{A}$} \\
\hline $\mathrm{CD}$ & & $2,80 \pm 0,20(3,33 \pm 0,24) A$ & \multicolumn{2}{|c|}{$2,83 \pm 0,18(3,37 \pm 0,21) \mathrm{A}$} \\
\hline AIC & $\left({ }^{\circ}\right)$ & $16,73 \pm 7,12 \mathrm{~B}$ & \multicolumn{2}{|l|}{$22,80 \pm 8,50 \mathrm{~A}$} \\
\hline AIT & $\left({ }^{\circ}\right)$ & $9,93 \pm 3,23 \mathrm{~A}$ & \multicolumn{2}{|l|}{$8,40 \pm 0,30 \mathrm{~A}$} \\
\hline DPTd & $\mathrm{cm}$ & $0,97 \pm 0,40 \mathrm{~A}$ & \multicolumn{2}{|l|}{$1,12 \pm 0,47 \mathrm{~A}$} \\
\hline DPTe & & $0,70 \pm 0,30 \mathrm{~B}$ & \multicolumn{2}{|l|}{$1,02 \pm 0,39 \mathrm{~A}$} \\
\hline $\mathrm{H}$ & & $5,77 \pm 1,64 \mathrm{~A}$ & \multicolumn{2}{|l|}{$5,89 \pm 1,74 \mathrm{~A}$} \\
\hline \multirow[t]{2}{*}{ VHS } & $\mathrm{CV}$ & $7,75 \pm 0,48 \mathrm{~A}$ & \multicolumn{2}{|l|}{$7,61 \pm 0,34 \mathrm{~A}$} \\
\hline & & Variação & Média \pm desvio & $\mathrm{CV} \%$ \\
\hline $\mathrm{AB} / \mathrm{CD}$ & $\mathrm{cm}(\mathrm{cv})$ & $1,14-1,45(1,18-1,21)$ & $1,29 \pm 0,07(1,08 \pm 0,06)$ & $5,52(5,55)$ \\
\hline $\mathrm{AB} / \mathrm{H}$ & & $0,56-0,86(0,47-0,72)$ & $0,70 \pm 0,05(0,56 \pm 0,042)$ & $7,14(7,5)$ \\
\hline $\mathrm{CD} / \mathrm{H}$ & & $0,48-0,70(0,40-0,58)$ & $0,54 \pm 0,04(0,45 \pm 0,03)$ & $7,40(6,66)$ \\
\hline
\end{tabular}

$\overline{\mathrm{AB}}=$ Comprimento apicobasilar do coração, $\mathrm{CD}=$ Largura máxima do coração perpendicular a AB, AIC= ângulo de inclinação cardíaca, AIT= ângulo de inclinação da traquéia, DPTd= Distância da parede cardíaca direita, DPTe $=$ Distância da parede cardíaca direita, $\mathrm{H}=$ Profundidade vertical do tórax, VHS= Vetebral heart scale.

* Médias seguidas de letras diferentes, na mesma linha, diferem estatisticamente.
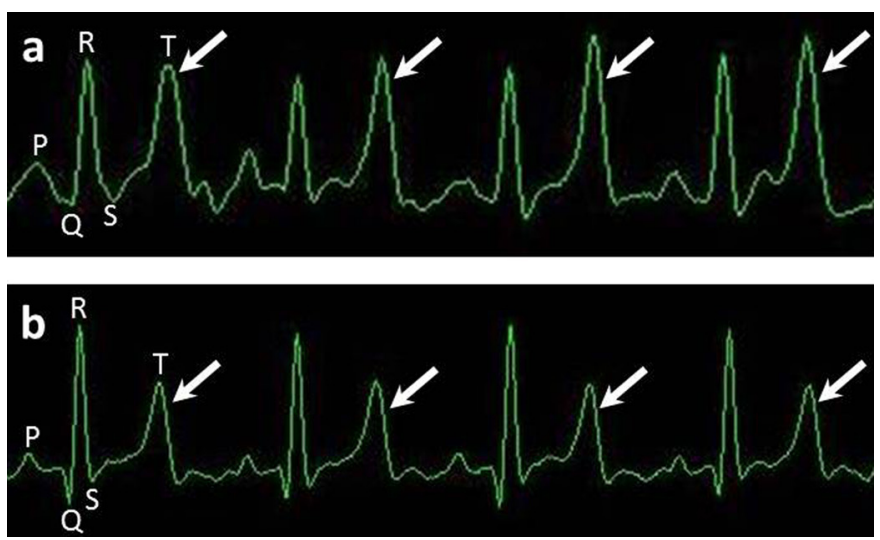

Fig.2. Example of a physiological electrocardiogram (ECG) of the agouti, analyzed in the bipolar II derivation (DII) $(25 \mathrm{~mm} / \mathrm{s}, 10$ $\mathrm{mm}=1 \mathrm{mV}$ ). (a) Shows the ECG pattern of the males. Note the presence of a great amplitude T-wave (arrow), reaching the peak of the R wave. (b) Shows the ECG tracing of the female. The T-wave also presents great amplitude compared to the $\mathrm{R}$ wave, but less intense than in the males.

the females. There was significant difference for the means of the PR interval, QRS complex and QT interval (PR interval: $p=0.01$; QRS duration: $p=0.0053$; QT interval duration: $p=0.027, p<0.05$ ). The $\mathrm{T}$ wave polarity (DII) was positive in $96.7 \%$ of the observations and negative in $32.22 \%$ of the occurrences. The heart rhythm observed was predominantly sinusal. The $\mathrm{T}$ wave amplitude was predominantly positive and there was polarity inversion in two animals of the experiment (DII) but no biphasic configuration was observed in the present study. For the males $(0.36 \pm 0.159$ $\mathrm{mV}$ ) the $\mathrm{T}$ wave was similar to that observed for the $\mathrm{R}$ wave amplitude $(0.366 \pm 0.205 \mathrm{mV})$, but for the females $(0.25 \pm 0.108 \mathrm{mV})$ the $\mathrm{T}$ wave amplitude was $70 \%$ greater than the $\mathrm{R}$ wave amplitude $(0.343 \pm 0.207 \mathrm{mV})$, and there was significant difference between males and females $(\mathrm{T}$ wave amplitude: $p=0.0078$. $p<0.05)$. The heart electric axis 


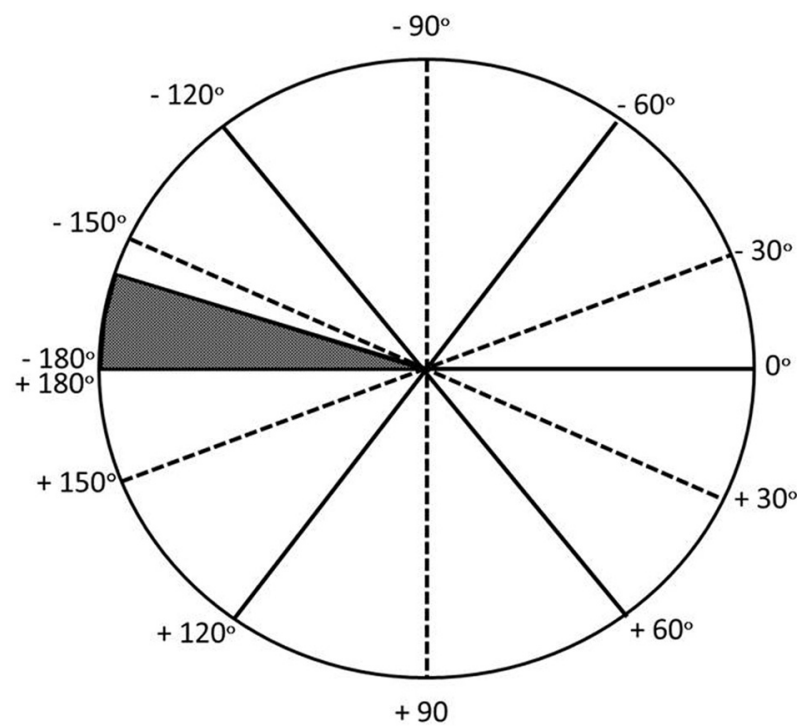

Fig.3. Heart electric axis obtained for agouti in frontal plane, by the sum of the positive and negative derivations in the I and III derivations.

varied from $-160^{\circ}$ to $+180^{\circ}$, with no significant difference between males and females (Fig.3).

\section{DISCUSSION}

Although most wild animals have certain requirements regarding handling, needing sedation or anesthesia $(\mathrm{Bu}-$ blot et al. 2006), the agouti used in the present experiment were calm and easy to handle and there was no need for chemical restraint, as has also been reported in ECG of non-anesthetized ferrets (Martin 2002).

The heart frequency (HF) in agouti was similar to that observed in domestic mammals such as the dog and cat (Martin 2002, Tilley 2002). When the results were compared to other wild mammals such as wolves $(142 \pm 29 \mathrm{bpm})$, leopards $(106.67 \pm 17.44 \mathrm{bpm})$ and cheetahs $(126 \pm 15$ bpm), the results were higher than for these animals (Schumacher et al. 2003, Estrada et al. 2009, Oda et al. 2009).

There was no significant difference when the HF was compared between male and female agouti. However, in a study carried out with physically constrained ferrets (Dudás-Györki et al. 2011) ECG tracings were shown with significantly different HF values between the males (210-315 bpm) and females (210 $\pm 396 \mathrm{bpm})$, and the mean values of this variable were greater for both the genders compared to the agouti. Similarly, in guinea pigs, the highest HF ranged from 240 to $310 \mathrm{bmp}$ (Cieslar et al. 1986). Under the same conditions, the rabbit HF was between 198 and 330 bpm (Reusch 2005) while in the skunk this variation was from 180 to $240 \mathrm{bpm}$ (Szabuniewicz \& Szabuniewicz 1978). It is important to emphasize that even without sedation or anesthesia the HF in the agouti was lower or within in the interval observed in the tracings of similar sized animals, this factor was probably associated to the level of adaptation of the agoutis to captivity management. To date, there are no references on the electrocardiogram tracing standards in agouti without chemical restraint.
The normal values of agouti ECG tracings showed similarities to that of the dog, cat (Tilley 1992) and exotic and wild mammals such as ferrets (Bublot et al. 2006) rabbits (Reusch 2005, Lord et al. 2010) guinea pigs (Cieslar et al. 1986) raccoons (Hamilin 1968) and skunk (Szabuniewicz \& Szabuniewicz 1978).

$\mathrm{P}$ wave duration in the agouti was closer to that observed in the cat $(0.035-0.04 \mathrm{~s})$ than in the dog, that has a slightly larger interval $(0.04-0.05 \mathrm{~s})$. When compared to anesthetized ferrets (Schoemaker and Zandvliet 2005) guinea pigs (Cieslar et al. 1986) and skunks (Szabuniewicz \& Szabuniewicz 1978), our results showed P wave values similar to those found for these animals. Allied to this, in non-anesthetized ferrets the $\mathrm{P}$ wave values did not differ from the mean values detected in the present study (Dudás-Györki et al. 2011). The $P$ wave duration seemed have similar results in the small sized species mentioned here. Some rabbit breeds can present pointed $\mathrm{P}$ wave, analyzed in derivation II without, however, it being related to a pathological condition (Reusch 2005).

The PR interval and the QRS complex in the agouti showed similar duration to that observed in cats and dogs and close to the mean values seen in humans (Kossmann 1953, Sawazaki et al. 1976). It is known that the patterns of both the PR and the QT intervals are inversely related to heart frequency. This rule was obeyed for agoutis without chemical restraint, and there were no variations in the PR interval duration, as was observed in ferrets (Dudás-Györki et al. 2011). When compared to non-anesthetized rabbits (Lord, Boswood \& Petrie 2010) the QRS complex values in the agouti were higher than those observed by these authors. The small variability in the QRS complex is in contrast with observations reported in rabbits (Slapak \& Hermanek 1957, Saitanov 1960, Szabuniewicz \& Szabuniewicz 1978). Although high repeatability of the ECG tracing was obtained, in rabbits a spontaneous variability was attributed to the looseness of the skin of these animals, a factor not observed in agouti. On the other hand, studies have shown that changes in the diaphragm position can lead to alterations in the heart position and consequently of the QRS complex (Slapak \& Hermanek 1957). It was observed in the maned sloth that the accumulation of gastric food content over 3 to 8 hours could displace the diaphragm, causing a change in the heart position and thus producing an effect on the QRS complex (Silva et al. 2005). The ECG tracings in the animals in the present study were always acquired early in the morning, a time when, for the experimental region, the temperature range is most comfortable, preventing heat stress. Since the agouti used in the present study had unlimited access to food, especially in the early morning and late afternoon, the possibility cannot be excluded that the diaphragm position did not influence the composition of the QRS complex in the agouti studied.

The QT interval value is considered essential when detecting abnormalities in heart polarization, such as the prolongation of this interval associated to the occurrence of arrhythmia (Eckardt et al. 1998). In rabbits, females were more susceptible to drug induced arrhythmia than males (Lu et al. 2001). Significant difference was observed in the 
present study for the QT interval between males and females, where the females showed greater duration of this interval characterizing a longer time for heart repolarization (Lord et al. 2010).

It is known that in domestic animals that the $\mathrm{T}$ wave amplitude should correspond to approximately $25 \%$ of the $\mathrm{R}$ wave (Martin 2002) and that in humans this ratio does not surpass a third of this proportion (Kossmann 1953). However, in the present study, the T-wave configuration in the agouti presented high repeatability and the $\mathrm{R} / \mathrm{T}$ ratio was different from that routinely reported in the literature. In both the male and female agouti, the T-wave had high amplitude values, when compared to the $\mathrm{R}$ wave. In humans the presence of great amplitude T-wave is observed in sinusal bradycardia (frequently in athletes), and in vagotonic individuals (Kambara \& Phillips 1976, Alimurung et al. 1980, Barbosa et al. 2004). In humans, the overlapping of the S-T segments and high T-wave amplitudes can occur in $2.5 \%$ to $14 \%$ of adult individuals, without evidence of cardiovascular or extracardiac diseases (Lazzoli et al. 2002). Further, Dixon and collaborators reported greater variability in the heart frequency under controlled ventilation in trained than in untrained individuals, translating as an increase in the vagal activity in rest in athletes (Dixon et al. 1992). Further on this aspect, the remodeling of the anatomic modulation of the heart, secondary to training, includes the reduction of sympathetic activity and increase in parasympathetic activity (Barbosa et al. 2004). It is further suggested that the number of cells that really polarized in the epicardial-endocardial direction, due to the even earlier start of epicardium repolarization, could create $\mathrm{T}$ waves with great amplitude (Barbosa et al. 2004, Dixon et al. 1992). Regarding animals, it was observed in racehorses that the T-waves presented great amplitude, corresponding to $43 \%$ of the $\mathrm{R}$ wave (Diniz et al. 2011).

Compared to non-anesthetized rabbits $(0.11 \mathrm{mV})$ and ferrets $(0.2 \mathrm{mV})$, the agouti T-wave presented amplitude values fourfold greater than the rabbit and twice as large as the ferret (Lord et al. 2010, Dudás-Györki et al. 2011). Unlike observations in humans, the T-wave morphology in small animals is very variable and the diagnostic value of the T-wave alterations is limited and depends on the assessment of previous ECG recordings of the same animal (Hamlin et al. 1956). In non-anesthetized rabbits, the T-wave amplitude was representative of $50 \%$ of the R wave (Lord et al. 2010) while in another study it was observed that in rabbits the T-wave was representative of $43 \%$ of the $\mathrm{R}$ wave (Reusch 2005) and a 46\% $\mathrm{T} / \mathrm{R}$ ratio in raccoons (Ribeiro et al. 2008) without, however, relating these values to a pathological condition in the animal studied.

The heart electric axis (EEC) represents the main direction of the electric current flow during the depolarization of the ventricles, and it is usually used to assess the ventricular increase or intraventricular defects (Hamlin et al. 1986). The EEC in agouti ranged from -160 to $180^{\circ}$. This variation differed consistently from the EEC pattern shown for most domestic species, such as the cat and the dog, and for other similar-sized rodents. Values have not been found in the literature for ECG determination in agouti to date.
Many EEC variations have been reported in ferrets (Bublot et al. 2006, Dudás-Györki et al. 2011). In rabbits, variations in the electric axis between -43 and $+80^{\circ}$ were closer to those obtained in the present study (Reusch 2005, Lord et al 2010). In rabbits it is suggested that the deviation to the left of the EEC is influenced by the thoracic shape found in the various breeds (Lord et al. 2010) and was also described for dogs (Tilley 1992). Although the present study used a significant number of animals $(n=30)$ it can be stated that there were no differences among the existing agouti species and further studies are needed on the morphological aspect of the thoracic cavity and the positioning of the heart in relation to the body in these animals.

\section{CONCLUSIONS}

This study established the first reference electrocardiogram values for the agouti.

Applying the ECG recording technique without chemical restraint was well tolerated, allowing the quick acquisition of reliable ECG tracings and high repeatability, which produced sufficient results to determine the heart rhythm and suggest measures of duration and amplitude of the ECG complexes.

The presence of a consistent statistical model represents the acquisition of the initial input for greater understanding of agouti heart electrophysiology but further studies are needed to define these parameters, taking into consideration agouti with their own myocardial pathogens.

Acknowledgements.- The authors thank for the support given to the research from the National Council for Scientific and Technical Development (CNPq) and the Federal University of Piauí, the Wild Animal Study and Research Nucleus (NEPAS) for logistic support and maintaining the animals studied.

\section{REFERENCES}

Alimurung B.N., Gilbert C.A., Felner J.M. \& Schlant R.C. 1980. The influence of early repolarization variant on the exercise electrocardiogram: a correlation with coronary arteriograms. Am. Heart J. 99:739-45.

Andrade J.N.B.M., Camacho A.A., Santos P.S.P., Fantinatti A.P., Newton N., Stopiglia A.J., Leal J.C. \& Braile D.M. 2004. Estudo da função ventricular na técnica de plicatura da parede livre do ventrículo esquerdo em cães. Revta Bras. Cir. Cardiovasc. 19:136-143.

Aptekmann K.P., Vailati M.C.F., Fortuna T.O.M. \& Schwartz D.S. 2010. Prevalence of cardiac arrhythmias and conduction disturbances in dogs and cats in Botucatu. Braz. J. Vet. Res. Anim. Sci. 47:371-379.

Barbosa E.C., Barbosa P.R.B., Bomfim A.S., Da Rocha P.J. \& Ginefr P. 2004. Repolarização Precoce no Eletrocardiograma do Atleta, bases Iônicas e Modelo Vetorial. Arq. Bras. Cardiol. 82:103-107.

Bartlett S.L., Abou-Madi N., Kraus M.S., Wiedne E.B. \& Starkey K. 2004. Electrocardiography of the Asian Elephant, Elephas maximus. J. Zoo Wildl. Med. 40:466-473.

Berllago H.G. \& Cerqueira R. 1994. Reproduction and growth of the opossum Monodelphis domestica (Mammalia: Didelphida) in Northeastern Brazil. J. Zool., Lond., 232:551-563.

Black P.A., Marshall C., Seyfried A.W. \& Bartin A.M. 2011. Cardiac assessment of African Hedgehogs, Atelerix albiventris. J. Zoo Wildl. Med. 42:4953

Bodmer R.E., Eisenberg J.F. \& Redford K.H. 1997. Hunting and the likelihood of extinction of Amazonian mammals. Conserv. Biol. 2:460-466.

Bublo I., Randolp R.W., Chalvet-Monfra K. \& Edwards N.J. 2006. The surface electrocardiogram in domestic ferrets. J. Vet. Cardiol. 8:87-93. 
Cieslar G., Sieron A., Rzepka E., Zmudziński J. \& Franek A. 1986. Normal electrocardiogram in guinea pig. Acta Physiol. 37:139-149.

Crissey S.D., Ange K.D., Slifka K.A., Kahn S.W.S. \& Ward A.M. 2004. Serum lipid concentrations in six canid and four ursid species in four zoos. J. Zoo Wildl. Med. 35:34-39.

Diniz M.P., Michima L.E.S. \& Fernandes W.R. 2011. Estudo eletrocardiográfico de equinos de salto sadios. Pesq. Vet. Bras. 31:355-361.

Diniz A.N., Silva-Junior J.R., Ambrosio C.E., De Sousa J.M., De Sousa V.R., Carvalho M.A.M., Nascimento D.N. \& Alves F.R. 2013. Thoracic and heart biometrics of non-anesthetized agouti (Dasyprocta primnolopha Wagler, 1831) measured on radiographic images. Pesq. Vet. Bras. 33: 411-416.

Dixon E.M., Kamath M.V., McCartney N. \& Fallen E.L. 1992. Neural regulation of heart rate variability in endurance athletes and sedentary controls. Cardiovasc. Res. 26:713-719.

Dudás-Györki Z., Szabó Z., Manczur F. \& Vörös K. 2011. Echocardiographic and electrocardiographic examination of clinically healthy, conscious ferrets. J. Small Anim. Pract. 52:18-25.

Eckardt L., Haverkamp W., Borggrefe M. \& Breithardt G. 1998. Experimental models of torsade de pointes. Cardiovasc. Res. 39:178-193.

Estrada A.H., Gerlach T.J., Schmidt M.K., Siegal-Willott J.L., Adrienne L., Atkins A.L., Scott B., Citino S.B. \& Padilla L.R. 2009. Cardiac evaluation of clinically healthy captive maned wolves, Chrysocyon brachyurus. J. Zoo Wildl. Med. 40:478-486.

Ferraz M.S., Menezes D.J.A., Pessoa G.T., Cabral R.M., Illera M.J., Silva A.R. \& Carvalho M.A.M. 2010. Collection and evaluation of epididymal sperm in captive agoutis, Dasyprocta aguti. Theriogenol. 75:459-462.

Fox M., Brieva C., Moreno C., MacWilliams P. \& Thomas C. 2008. Hematologic and serum biochemistry reference values in wild-caught whitefooted tamarins, Saguinus leucopus, housed in captivity. J. Zoo Wildl. Med. 39:548-557.

Gardne A., Thompson M.S., Fontenot D., Gibson N. \& Heard D.J. 2007. Radiographic evaluation of cardiac size in flying fox species (Pteropus rodricensis, P. hypomelanus and P. vampyrus). J. Zoo Wildl. Med. 38:192200.

Gava F.N., Paulino-Junior D., Pereira-Neto G.B., Pascon J.P.E., Sousa M.G., Champion T. \& Camacho A.A. 2011. Computerised electrocardiograph in Beagle dogs. Arq. Bras. Med. Vet. Zootec. 63:317-321.

Hamilin R.L. 1968. Analisys of cardiac silhouette in dorsoventral radiographs from dogs with heart disease. J. Am. Vet. Med. Assoc. 153:14441460.

Hamlin R.L., Hren J. \& Sparrow P.V. 1986. Electrocardiographic evaluation of the healthy raccoon, Procyon lotor. Am. J. Vet. Res. 47:814-817.

Hanton G. \& Rabemampianina Y. 2006. The electrocardiogram of the Beagle dog: reference values and effect of sex, genetic strain, body position and heart rate. Lab. Anim. 40:123-136.

Heatley J.J. 2009. Cardiovascular anatomy, physiology and disease of rodent and small exotic mammals. Vet. Clin. North Am., Exot. Anim. Pract. 12:99-113.

Hosken F.M. 2001. Manejo de Cutias, p.21-22. In: Hosken F.M. \& Silveira A.C. (Eds), Criação de Cutias. Aprenda Fácil, Viçosa, MG.

Kambara H. \& Phillips J. 1976. Long-term evaluation of early repolarization syndrome (normal variant RS-T segment elevation). Am. J. Cardiol. 38:157-61.

Kossmann C.E. 1953. The normal electrocardiogram. Circulation 8:920936.

Lazzoli J.K., Castro C.L.B., Nóbrega A.C.L. \& Araújo C.G.S.A. 2002. Acurácia de critérios para vagotonia no eletrocardiograma de repouso de 12 derivações: uma análise com curvas ROC. Revta Bras. Med. Esp. 8:50-58.

Leal I.R., Da Silva J.M.C., Tabarelli M. \& Lacher Jr T.E. 2005. Changing the course of biodiversity conservation in the caatinga of northeastern Brazil. Conserv. Biol. 19:701-706.

Lopes J.B., Cavalcante R.R., Almeida M.M., Carvalho M.A.M., Moura S.G., Dantas-Filho L.A. \& Conceição W.L.F. 2004. Desempenho de Cutias, Dasy- procta prymnolopha, criadas em cativeiro do nascimento até o desmame em Teresina, Piauí. Revta Bras. Zootec. 33:2318-2322.

Lord B., Boswood A. \& Petrie A. 2010. Electrocardiography of the normal domestic pet rabbit. Vet. Rec. 167:961-965.

Lu H.R., Remeysen P., Somers K., Saels A. \& De Clerck F. 2001. Female gender is a risk factor for drug-induced 1long QT and cardiac arrhythmias in an in vivo rabbit model. J. Cardiovasc. Electrophysiol. 12:538-545.

Martin M. 2002. ECG interpretation in small animals: practical guidelines. In Practice 24:250-261.

Neto G.B.P., Márcio A., Brunetto M.A., Sousa M.G., Carciofi A.C. \& Camacho A.A. 2010. Effects of weight loss on the cardiac parameters of obese dogs. Pesq. Vet. Bras. 30:167-171.

Nogueira-Filho S.L.G. \& Nogueira S.S.C. 2000. Criação comercial de animais silvestres: produção e comercialização da carne e de subprodutos na região sudeste do Brasil. Revta Econom. Nord. 31:188-195.

Oda S.G.S., Yamat R.J., Fedullo J.D.L., Neto M.L. \& Larsson M.H.M. 2009. Standardization of some electrocardiographic parameters of captive leopard cats, Leopardus tigrinus. J. Zoo Wildl. Med. 40:414-420.

Onuma M., Kondo H., Ono S., Ueki M., Shibuya H. \& Sato T. 2009. Radiographic measurement of cardiac size in 64 ferrets. J. Vet. Med. Sci. 71:355-358.

Osofsky A., Jowett P.L.H., Hosgood G. \& Tully T.N. 2001. Determination of normal blood concentrations of lead, zinc, copper, and iron in Hispaniolan Amazon parrots, Amazona ventralis. J. Avian Med. Surg. 15:31-36.

Pinheiro R.M., Andrade S.A. \& Cunha J.N. 1989. Preservação e exploração de animais silvestres nativos: preá, cutia e mocó. Caatinga 6:28-49.

Redford K.H. 1997. Manejo e conservação de vida silvestre no Brasil, p.122.. In: Redford K.H. (Ed.), A Floresta Vazia, Mamirauá, AM.

Reusch B. 2005. Investigation and management of cardiovascular disease in rabbits. In Practice 27:418-425.

Ribeiro A.S.S., Palha M.D.C., Tourinho M.M., Whiteman C.W. \& Da Silva A.S.L. 2007. Utilização dos recursos naturais por comunidades humanas do Parque Ecoturístico do Guamá, Belém, Pará. Acta Amazôn. 37:235240.

Ribeiro E.E.A., Batista M.C.S., Carvalho M.A.M. \& Silva J.A.L. 2008. Hemograma e proteinograma de cutias (Dasyprocta sp.) hígidas, criadas em cativeiro: influência do sexo e da idade. Arq. Bras. Med. Vet. Zootec. 60:1123-1127.

Saitanov A.0. 1960. Standard and thoracic lead electrocardiography in normal rabbits and methods for its registration. Biulleten Eksperimental'noi Biologii I Meditsiny 49:102-109.

Sampaio Y. \& Batista J.E.M. 2004. Desenvolvimento regional e pressões antrópicas no bioma Caatinga, p.311-324. In: Sampaio Y. \& Batista J.E.M. (Eds), Biodiversidade da Caatinga: áreas e ações prioritárias para a conservação. Ministério do Meio Ambiente, Brasília.

Sawazaki H., Hirose H., Matsui K., Yamori K. \& Hanyu I. 1976. Comparative electrocardiographical studies on the wave form of QRS complex in vetebrates. J. Vet. Sci. 38:235-240.

Scheer P., Svoboda P., Sepsi M., Janecková K. \& Doubek J. 2010. The electrocardiographic Holter monitoring in experimental veterinary practice. Physiol. Res. 1:59-64.

Schoemaker N.J. \& Zandvliet M.M. 2005. Electrocardiography in Psittacine birds and ferrets. Semin. Avian Exot. Pet Med. 14:34-51.

Schumacher J., Snyder P., Scott B., Citino S.B., Bennett R.A. \& Dvorak L.D. 2003. Radiographic and electrocardiographic evaluation of cardiac morphology and function in captive cheetahs Acinonyx jubatus. J. Zoo Wildl. Med. 34:357-363.

Silva E.M., Duarte D.P.F. \& Costa C.P. 2005. Electrocardiographic studies of the three-toed sloth, Bradypus variegatus. Braz. J. Med. Biol. Res. 38:1885-1888.

Slapak L. \& Hermanek P. 1957. Observations on the electrocardiogram of rabbits. Zeitschrift für Kreislaufforschung 46:136-142.

Stepien R.L., Benson K.G. \& Forrest L.J. 1999. Radiographic measurement of cardiac size in normal ferrets. Vet. Radiol. Ultrasound 40:606-610. 
Szabuniewicz J.M. \& Szabuniewicz M. 1978. The electrocardiogram of the Virginia opossum Didelphis virginiana. Zentralbl. Veterinärmed. 25:785-793.

Tilley L.P. 1992. Tables for determining the frontal plane mean electrical axis, p.443-447. In: Tilley L.P. (Ed.), Essentials of Canine and Feline Electrocardiography. $3^{\text {rd }}$ ed. Lippincott Williams and Williams, Philadelphia.
Tilley L.P. 1981. Basic canine and feline electrocardiography. Can. Vet. J. 22:23-24

Ware W.A. 2007. Overview of cardiac radiography, p.34-36. In: Ware W.A. (Ed.), Cardiovascular Disease in Small Animal. $2^{\text {nd }}$ ed. Manson Publishing, London. 